\title{
PATTERNS OF STRUCTURAL FAILURES IN URBAN TREES: COAST LIVE OAK (QUERCUS AGRIFOLIA)
}

\author{
by Roger Edberg' and Alison Berry ${ }^{2}$
}

\begin{abstract}
Data from the California Tree Failure Report Program (CTFRP) were analyzed to develop a profile of the structural failure characteristics for coast live oak (Quercus agrifolia). The most common pattern of structural failure for coast live oak reported in the CTFRP is a root or low trunk failure of a naturally occurring tree growing in a residential site. Decay, site grade changes, and low wind speeds are significantly more frequently associated with coast live oak failures than with other hardwoods, conifers, or eucalyptus. Decay of roots and lower trunk was a major contributing factor to failure of coast live oak (83\%). Saturated soil conditions associated with root failure were also more frequent for coast live oak than for other species groups. Careful attention to controlling excess soil moisture, avoiding or correcting grade change and compaction, and monitoring decay are essential to maintain the health of coast live oak.
\end{abstract}

This paper presents a failure profile for coast live oak (Quercus agrifolia) derived from the California Tree Failure Report Program (CTFRP) data. The value of a database approach to tree failure analysis and the purpose of the CTFRP have been discussed earlier (Costello and Berry 1991). A failure profile for a given tree species consists of analysis of factorsenvironmental or structural-that are associated with failure. Factors considered in the CTFRP report form are failure location (at the trunk, on a branch, or at the root), tree size, tree stand information (natural, planted), observable structural defects, cultural practices, site and weather conditions, and decay. In analyzing the CTFRP data, the factors are summarized as frequencies and/or crosstabulation matrices (e.g., failure location versus wind speed or precipitation).

Failures of coast live oak are the most frequently reported of hardwood species in the CTFRP database and are the third most frequently reported of all species, representing $9 \%$ of the total number of reports (122 of 1,467 cases, June 1995). A failure profile for Monterey pine has been published (Edberg et al. 1994)_the most frequently occurring species in the database ( $15 \%$ of failure reports). Coast live oak failures may be expected to differ greatly from those of Monterey pine in that the oaks are typically native trees that have become part of the urban landscape through development rather than having been planted into the landscape.

Coast live oak is an evergreen oak native to California, growing up to $21 \mathrm{~m}(70 \mathrm{ft})$ in height, with a spreading, round-headed, often multi-stemmed crown. The trees are commonly found in the coastal ranges of central California, most abundantly in open valleys and lower slopes as part of the California Foothill Woodland Community. In the northern reaches of its range, coast live oak is usually found below $915 \mathrm{~m}(3,000 \mathrm{ft})$ elevation, while in the south it may be found at elevations as high as $1,525 \mathrm{~m}$ $(5,000 \mathrm{ft})$. At the borders of its range, it hybridizes with interior live oak (Q. wislizenii) (Griffin and Critchfield 1972).

Failure reports in the CTFRP for coast live oak have come mainly from coastal counties, where oak woodlands and grasslands have been developed into densely populated major urban and suburban areas. San Mateo County contributed $22 \%$ of all coast live oak CTFRP failure reports; Santa Clara County contributed 20\%; Ventura, 12\%; Contra Costa, $9 \%$; and Santa Barbara, $8 \%$.

\section{METHODS}

The California Tree Failure Report Program survey form and the data categories have been described previously (Costello and Berry 1991). Standardized report forms are completed by tree workers, arborists, or consultants encountering a structural tree failure and are submitted to the CTFRP. The data were compiled with dBaseIV database software. Coast live oak failure reports were analyzed using the dBStats (Ashton-Tate) statistical package. Custom applications were written for dBStats to perform repeated comparisons between species based on various data fields, logical tests for the creation of screened fields, and 
field and value labeling for printout readability. Data from selected tree failure report form fields were grouped into categories to facilitate specific comparisons. For example, a new field was created by the software application to divide data from the "location of failure" field into the general categories "above ground" (trunk failures above ground level) and "at or below ground level" (trunk failures at ground level and root failures) to compare soil-level problems to above-ground-level problems. Missing information was screened from individual fields and removed from statistical analysis.

For general data descriptions, frequency tables (percentage of population) were used directly or in combination with sorting features to establish additional categories (such as height classes or "other oaks"). Crosstabulation of fields (i.e., tree group vs. failure location) was analyzed using the $\chi^{2}$ test on $2 \times 2$ or $2 \times 3$ contingency or crosstabulation tables (Geng and Hills 1989), where $P$ indicates the probability that compared groups share the same distribution of values. Where data for tree age are used, it should be noted that in most cases age was estimated to the best of the ability of the reporter and that accurate age estimation is often difficult due to species and site variability.

Comparisons with 5 other major groups in the CTFRP database were useful in defining the characteristic failure patterns of coast live oak. For the purpose of comparison, a group may be defined as a single species, such as valley oak ( $Q$. lobata); as a grouping by genus (Eucalyptus); or as a larger grouping of many genera, for example, all hardwoods or all conifers. Such defined groups are most useful if they are reported frequently in the database, as is the case for valley oak ( $5 \%$ of the total), and eucalyptus (12.6\% of the total). We have separated eucalyptus from the hardwood category because it exhibits failure characteristics more similar to conifers than to other hardwoods.

\section{RESULTS}

Coast live oaks and other oaks in general are typically trees indigenous to the site ( $80 \%$ of coast live oak reported). In contrast, approximately $90 \%$ of other hardwood species, eucalyptus, and conifers in the database are planted trees. Coast live oak failures were reported most frequently ( $57 \%$ ) from residen- tial sites. Eucalyptus and conifer failures were commonly reported from parks (39\% and 56\%, respectively). Failures of "other hardwoods" were reported most often from residential (36\%) and street tree (28\%) sites.

Coast live oaks, valley oaks, and "other oaks" (the remainder of species excluding $Q$. agrifolia and $Q$. lobata grouped together) failed at a significantly higher reported age $(110,110$, and 156 years mean, respectively) than other hardwoods, eucalyptus, or conifers (33, 40, and 60 , respectively). The mean reported age of valley oak (156 years) was significantly higher than all other tree groups. When comparing mean dbh (diameter at breast height), coast live oaks (88 cm [35 in.]), other oaks $(80 \mathrm{~cm}$ [32 in.]), conifers $(88 \mathrm{~cm})$, and valley oaks $(108 \mathrm{~cm}$ [45 in.]) were significantly larger than other hardwoods and eucalyptus (50 and $65 \mathrm{~cm}$ [20 and 26 in.], respectively). Valley oak was significantly larger than all other tree groups.

\section{Location of Failure}

The most general structural characteristic of any tree failure is where it occurs on the tree, whether on the trunk, branches, or at the roots. In Table 1, the relative distribution of failure locations is compared among the 6 tree groups. These distributions were tested for significant differences by pairs of groups in a 2 (tree group) $\times 3$ (location of failure) cell matrix using the $\chi^{2}$ test. Coast live oak failed most frequently at the root system ( $45 \%$ of reports). However, the $\chi^{2}$ probability was not significant between coast live oak and other hardwoods (0.13), valley oak (0.16), or other oaks (0.36), even though these groups had a relatively more uniform distribution of location of failure. Eucalyptus and conifer species shared a common distributional pattern for location of failure $\left(\chi^{2} P=0.44\right)$ with a high percentage of branch failures. Both eucalyptus and conifer location of failure distributions were significantly different from the hardwood group and from coast live oak $\left(\chi^{2} P<0.001\right)$.

Another way of looking at the location of failure is to group failures into those occurring at the ground level or below (including ground level trunk failures and root failures) and those occurring above ground level (trunk failures occurring above ground level and branch failures). Using these groupings 
Table 1. Frequency of location of failure (\%) by tree group. Failure location percentage also divided into failures occurring at ground level (trunk) plus below (root) and failures occurring above ground (trunk above ground level and branch).

\begin{tabular}{lllllll}
\hline Location of failure & Q. agrifolia & Hardwoods & Eucalyptus & Conifers & Q. lobata & Other oaks \\
\hline Trunk (\%) & 28.9 & 30.6 & 28.1 & 23.6 & 33.8 & 31.3 \\
Branch (\%) & 26.4 & 34.2 & 53.0 & 55.0 & 35.1 & 33.8 \\
Root (\%) & 44.6 & 35.2 & 18.9 & 21.4 & 31.1 & 35.0 \\
$\begin{array}{l}\text { Ground level } \\
\quad \text { and below (\%) }\end{array}$ & 54.0 & 45.0 & 24.0 & 25.0 & 35.0 & 45.0 \\
$\begin{array}{l}\text { Above ground } \\
\text { level (\%) }\end{array}$ & 46.0 & 55.0 & 76.0 & 75.0 & 65.0 & 55.0 \\
\hline
\end{tabular}

Table 2. Location of failure vs. percentage (of group total) associated with decay (all decay types combined).

\begin{tabular}{lllllll}
\hline Decay & Q. agrifolia & Hardwoods & Eucalyptus & Conifers & Q. lobata & Other oaks \\
\hline Trunk (\%) & 97 & 65 & 50 & 40 & 71 & 79 \\
Branch (\%) & 73 & 33 & 28 & 13 & 62 & 80 \\
Root (\%) & 78 & 69 & 51 & 37 & 91 & 96 \\
All locations (\%) & 83 & 55 & 39 & 24 & 75 & 86 \\
\hline
\end{tabular}

Table 3. $\mathrm{Chi}^{2}$ probabilities from 32 individual $2 \times 2$ matrices. Decay (presence or absence) by tree group (pairwise).

\begin{tabular}{lllllllll}
\hline & Qax & Qax & Qa $\times$ & Qax & AllOak $\times$ & HW $\times$ & HW $\times$ & Euc $\times$ \\
Decay & HW & Ql & Q other & euc & HW & con & euc & con \\
\hline Trunk & $<0.001$ & 0.01 & 0.07 & $<0.001$ & $<0.001$ & $<0.001$ & 0.09 & NSD \\
Branch & $<0.001$ & NSD & NSD & $<0.001$ & $<0.001$ & $<0.001$ & NSD & $<0.001$ \\
Root & NSD & NSD & 0.07 & 0.02 & $<0.001$ & $<0.001$ & 0.06 & NSD \\
All locations & $<0.001$ & NSD & NSD & $<0.001$ & $<0.001$ & $<0.001$ & $<0.001$ & $<0.001$ \\
\hline
\end{tabular}

$\mathrm{Qa}=\mathrm{Q}$. agrifolia, $\mathrm{Ql}=\mathrm{Q}$. lobata, $\mathrm{Q}$ other $=$ Quercus other, euc $=$ eucalyptus, con $=$ conifer, $\mathrm{HW}=$ hardwood.

(Table 1), the failure pattern of coast live oak ( $46 \%$ above ground level, $54 \%$ at or below) is significantly different than that of hardwoods $\left(\chi^{2} P=0.07\right)$, and valley oak $\left(\chi^{2} P=0.02\right)$.

\section{Decay}

Coast live oak, like other oaks in the database, had a higher incidence of decay associated with failure compared with the remaining hardwoods in the database, with conifers, or with eucalyptus. Table 2 shows the frequency of decay associated with failure for these tree groups, separated by failure location. "Decay" combines together all decay types (heart, sap, etc.) reported as associated with failure under "decay type" on the tree failure report. $\mathrm{Chi}^{2}$ probabilities are assembled in Table 3 for $2 \times 2$ matrix comparisons between pairs of tree groups from
Table 2 and the decay index (presence or absence). The "all oak" group pools all oak species.

Decay was associated with failure in oak more frequently than in other hardwoods (e.g., $83 \%$ of all failures for coast live oak). Individually, there appear to be differences among the oaks. Coast live oak had significantly higher association of decay with failure than other hardwoods except at the root. Coast live oak had a lower association of decay with failure at the root than other oaks. Coast live oak had a significantly higher decay associated with trunk failure than Q. lobata.

\section{Structural Defects}

Tree structural defects are potentially important factors contributing to a failure. The California Tree Failure Report Program includes a category for re- 
Table 4. Structural defects most frequently associated with failure. Percentage is of the total number of failures for each tree group.

\begin{tabular}{|c|c|c|c|c|c|c|}
\hline $\begin{array}{l}\text { Top } \\
\text { three }\end{array}$ & Q. agrifolia & Hardwoods & Eucalyptus & Conifers & Q. lobata & Other oaks \\
\hline 1 & $\begin{array}{l}\text { Failed portion } \\
\text { dead (root) } \\
11.2 \%\end{array}$ & $\begin{array}{l}\text { Heavy lateral } \\
\text { limbs (branch) } \\
9.2 \%\end{array}$ & $\begin{array}{l}\text { Heavy lateral } \\
\text { limbs (branch) } \\
18.5 \%\end{array}$ & $\begin{array}{l}\text { Heavy lateral } \\
\text { limbs (branch) } \\
36.5 \%\end{array}$ & $\begin{array}{l}\text { Heavy lateral } \\
\text { limbs (branch) } \\
9.6 \%\end{array}$ & $\begin{array}{l}\text { Heavy lateral } \\
\text { limbs (branch) } \\
17.7 \%\end{array}$ \\
\hline 2 & $\begin{array}{l}\text { Multiple trunks/ } \\
\text { codominant } \\
\text { stems (trunk) } \\
8.6 \%\end{array}$ & $\begin{array}{l}\text { Multiple trunks/ } \\
\text { codominant } \\
\text { stems (trunk) } \\
8.7 \%\end{array}$ & $\begin{array}{l}\text { None (branch) } \\
9.8 \%\end{array}$ & $\begin{array}{l}\text { Multiple trunks/ } \\
\text { codominant } \\
\text { stems (trunk) } \\
6.3 \%\end{array}$ & $\begin{array}{l}\text { Failed portion } \\
\text { dead (root) } \\
8.2 \%\end{array}$ & $\begin{array}{l}\text { Failed portion } \\
\text { dead (trunk) } \\
11.4 \%\end{array}$ \\
\hline 3 & $\begin{array}{l}\text { Failed portion } \\
\text { dead (trunk) } \\
7.8 \%\end{array}$ & $\begin{array}{l}\text { Failed portion } \\
\text { dead (trunk) } \\
6.5 \%\end{array}$ & $\begin{array}{l}\text { Multiple } \\
\text { branches } \\
\text { one point } \\
\text { (branch) } 8.7 \%\end{array}$ & $\begin{array}{l}\text { Multiple trunks/ } \\
\text { codominant } \\
\text { stems (branch) } \\
6.3 \%\end{array}$ & $\begin{array}{l}\text { Heavy lateral } \\
\text { limb (trunk) } \\
5.5 \%\end{array}$ & $\begin{array}{l}\text { None (root) } \\
8.9 \%\end{array}$ \\
\hline
\end{tabular}

cording structural defects, such as multiple trunks/ codominant stems, dense crown, leaning trunk, cracks/splits, kinked or girdling roots, and others. Table 4 includes the defects that had the 3 highest values for percentages of failure within each of the 6 tree groups. The most frequently occurring structural defect/failure location combination for coast live oak was "failed portion dead" at the root. The most frequently occurring structural defect/location combination for all tree groups other than coast live oak was a branch failure associated with heavy lateral limbs. For conifers, branch failure was an exceptionally high percentage ( $36.5 \%$ of all failures); for eucalyptus and "other oaks" it was a high percentage (about 18\%), and for hardwoods and valley oaks it was about $10 \%$, slightly higher than the next most frequent failure combinations.

The structural defect "failed portion dead" was commonly associated with both root and trunk failure of coast live oak, together accounting for $19 \%$ of reported failures. It did not show up as a major factor for eucalyptus or conifer failures. Hardwoods, other oaks, and valley oaks also had a lesser percentage of failures associated with dead portions of trunk or roots $(6.5 \%, 11.4 \%$, and $8.2 \%$, respectively).

\section{Environmental Conditions at Time of Failure}

Environmental conditions occurring at the time of a tree structural failure may be a contributing factor to that failure or may indicate threshold conditions for a particular species or tree group. The CTFRP report form has fields for reporting wind speed and direction, precipitation, temperature, soil condition, and site topography at the time of failure.

Precipitation. The failure report form contains several data fields related to precipitation, including rain, fog, or snow. Table 5 lists the percentage of failures involving some type of precipitation by location of failure for each of the comparison tree groups. One consistent association we observed was that root failures for all tree groups frequently occurred in association with precipitation (e.g., $73 \%$ of Q. agrifolia failures occurring with precipitation). For coast live oak, trunk and branch failures were not commonly associated with precipitation. For the comparison in Table 5, all positive responses were grouped and compared to failures occurring in the absence of precipitation.

$\mathrm{Chi}^{2}$ probabilities were calculated for 36 individual $2 \times 2$ crosstabulation tables comparing pairs of tree groups by precipitation at each location of failure and at all failure locations combined. Root failure was frequently associated with precipitation for all groups except conifers. There were no significant differences for failures at the root in relation to precipitation except between coast live oak and conifers. There was no significant difference between coast live oak and valley oak at any location, but there was between coast live oak and other oaks at all locations but root failures. There was significant 
difference between coast live oaks and conifers at all locations.

Wind speed. Table 6 lists failures associated with wind speed by location of failure and tree group. By contrast, for most tree groups other than oaks, failure events are often associated with wind (overall more than 75\%). Coast live oak failures at all locations occurred more frequently (49\%) at low wind speeds (less than $5 \mathrm{mph}$ [8 $\mathrm{kph}]$ ) than was the case for other groups, except valley oak.

$\mathrm{Chi}^{2}$ analysis showed a significant difference in wind speed associated with failure at all locations between coast live oak and "other hardwoods," between coast live oak and eucalyptus, and between coast live oak and conifers. Eucalyptus, conifers, and "other hardwoods" showed no (or slight) significant differences among themselves, as did the oak categories among themselves.

Soil. Soil condition at the time of tree failure or previous to the failure may be one causal factor. Table 7 lists the association of saturated soil with failure location for the tree groups. Coast live oak seems to have a high association of saturated soil with root failure (30\% overall). In terms of $\chi^{2}$ probabilities, coast live oak had significantly higher association of saturated soil with root failure than all other tree groups except for the hardwood category.

Site topography. The "site topography" field on the CTFRP report form contains 6 choices: excavation, grade change (cut, grade change, fill), streambank erosion, slope erosion, or not applicable. Observation of the data shows a high frequency of grade change (cut or fill) associated with coast live oak (29.6\% overall) and other oak failures (Table 8 ). To assemble crosstabulation tables into meaningful comparisons that may be tested statistically, both grade change choices were grouped together and compared to the remaining choices for the field. Failures in coast live oak, valley oak, and the "other oak" group were frequently associated with grade change. The oaks did not show significant differences among themselves.

Table 5. Percentage of failures associated with precipitation for each location of failure (root, trunk, or branch) and for all locations grouped (all failure locations). Rain, fog, and snow are combined.

\begin{tabular}{lllllll}
\hline Location of failure & Q. agrifolia & Hardwoods & Eucalyptus & Conifers & Q. lobata & Other oaks \\
\hline Trunk (\%) & 18 & 37 & 39 & 57 & 9 & 59 \\
Branch (\%) & 10 & 17 & 43 & 60 & 26 & 48 \\
Root (\%) & 73 & 66 & 73 & 57 & 65 & 69 \\
All locations (\%) & 40 & 40 & 48 & 59 & 34 & 59 \\
\hline
\end{tabular}

Table 6. Percentage of failures for each location of failure and for all locations grouped by wind speeds less than or equal to $5 \mathrm{mph}(8 \mathrm{kph})$.

\begin{tabular}{lllllll}
\hline Location of failure & Q. agrifolia & Hardwoods & Eucalyptus & Conifers & Q. lobata & Other oaks \\
\hline Trunk (\%) & 52 & 17 & 28 & 24 & 73 & 59 \\
Branch (\%) & 63 & 32 & 28 & 28 & 52 & 53 \\
Root (\%) & 36 & 8 & 12 & 17 & 46 & 17 \\
All locations (\%) & 49 & 19 & 25 & 25 & 57 & 36 \\
\hline
\end{tabular}

Table 7. Percentage of failures associated with saturated soil, by failure location.

\begin{tabular}{lcccccc}
\hline Location of failure & Q. agrifolia & Hardwoods & Eucalyptus & Conifers & Q. lobata & Other oaks \\
\hline Trunk (\%) & 2 & 4 & 4 & 5 & 4 & 4 \\
Branch (\%) & 1 & 2 & 5 & 11 & 3 & 5 \\
Root (\%) & 27 & 19 & 5 & 7 & 11 & 12 \\
All locations (\%) & 30 & 25 & 14 & 23 & 18 & 21 \\
\hline
\end{tabular}


Table 8. Grade change-cut or fill versus other choices combined from the report form field "site topography." Percentage of failures at each location associated with a grade change.

\begin{tabular}{lllllll}
\hline Location of failure & Q. agrifolia & Hardwoods & Eucalyptus & Conifers & Q. lobata & Other oaks \\
\hline Trunk (\%) & 7.6 & 1.6 & 1.8 & 1.1 & 5.8 & 5.5 \\
Branch (\%) & 7.6 & 1.0 & 1.0 & 2.5 & 8.7 & 5.5 \\
Root (\%) & 14.4 & 1.6 & 1.8 & 2.3 & 11.6 & 9.6 \\
All locations (\%) & 29.6 & 4.2 & 4.6 & 5.9 & 26.1 & 20.6 \\
\hline
\end{tabular}

\section{DISCUSSION}

Overall, the most common combined pattern of structural failure for coast live oaks reported in the CTFRP was a root or low trunk failure of a naturally occurring tree growing in a residential site (Figure 1). Coast live oaks reported in the CTFRP failed most often at the root ( $45 \%$ of $Q$. agrifolia). When trunk failures at ground level were combined with root failures, coast live oak had a significantly higher frequency for ground-level and below-ground failures than other tree groups (Table 1). This places the major failure problem area for coast live oak at the soil level and below, suggesting that human site and soil modification can have a negative impact on the health of these remnant trees of native origin. Site grade changes, both cutting and filling, were frequently associated with the failures of native oaks. Coast live oak in particular has the highest frequency of grade change associated with failure (18\% fill and $12 \%$ cut). Reduced gas exchange under compacted soil or fill conditions has been shown to correlate with decline symptoms in oaks (MacDonald et al. 1993). Low oxygen conditions reduce root growth and increase disease severity

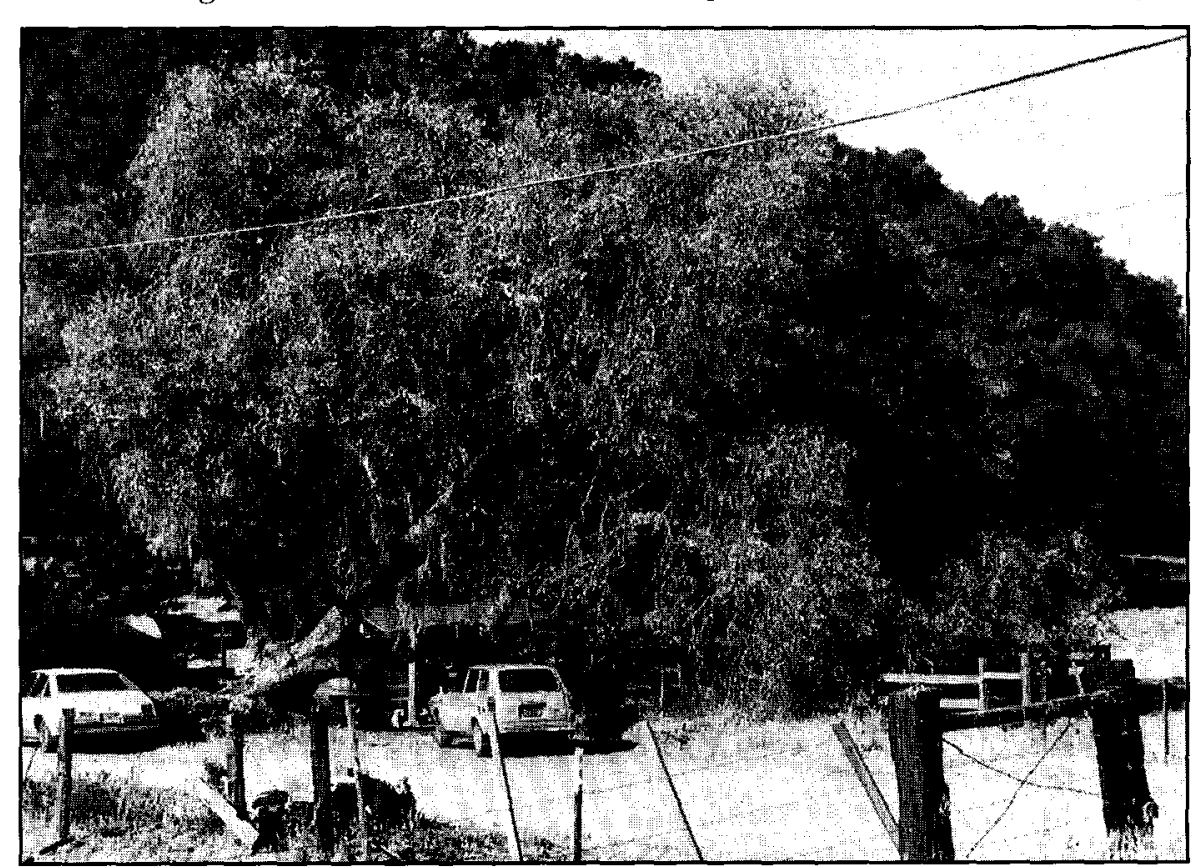

Figure 1. Failure of Q. agrifolia in San Luis Obispo County, California. The tree had a dbh of $100 \mathrm{~cm}(40.5 \mathrm{in}$.). It failed at the roots during heavy spring rains, with soggy soil and gusty winds. The failed tree had been growing in a residential setting that was a native stand prior to human occupancy (visible in the background). Note the soil disturbances: Herbaceous ornamentals were planted around the base of the tree, requiring irrigation on the trunk and root system; and vehicle traffic, parked cars, etc. extended almost to the trunk. Root decay was present. This photo was taken by CTFRP cooperator Ted Elder 1 to 2 months after the failure. 
well, placing greater stress on weakened or dead root system components.

Decay and dead wood were significantly more frequently associated with coast live oak failures than with failures in other tree groups. Eighty-three percent of failures were associated with decay in coast live oaks, similar to the decay pattern observed in other oaks (86\%). Decay is thus a major contributing factor to tree failure in coast live oaks. Decay data are hard to interpret. While oaks in general have a higher association of decay with failure than other tree groups, they also fail at a higher reported age than other tree groups and at a larger dbh by a factor of at least 2 . While tree age may be a questionable measure due to the imprecision of visual estimation, the older nature of the oak population seems to be reflected in the dbh data. Published dbh tables for Q. agrifolia were unavailable; however, dbh tables for Q. kelloggii indicate that a $88-\mathrm{cm}$ (35-in.) dbh (the average dbh for $Q$. agrifolia failures) corresponds to an age of 200 years (Burns and Honkala 1990). The oak population's apparent older age before failing may suggest that oaks are actually more resistant to decay rather than more susceptible, or that oak wood is of higher strength and can withstand a greater loss of sound wood before failing. There are few data regarding the percentage of decay in the wild for coast live oak or regarding the age of onset of decay in oaks that have failed.

A large proportion of coast live oak failures ( $49 \%$ of failures overall) occurred in conditions where wind speed was less than $5 \mathrm{mph}(8 \mathrm{kph})$. At a lower wind speed, trees experience a lower bending stress. Our finding that these trees frequently fail at lower wind speeds, together with decay and structural defect data described above, suggests that a substantial decline in structural strength had already occurred in coast live oaks before the trees failed.

\section{MANAGEMENT STRATEGIES}

Our findings confirm that, to maintain the health of coast live oak and California oaks in general, careful attention to controlling excess soil moisture and avoiding or correcting grade disturbance and compaction is essential, as is monitoring decay throughout the tree, especially in below-ground portions (Britton 1990).

\section{LITERATURE CITED}

Britton, J.C. 1990. Root crown examinations for disease and decay. J. Arboric. 16(7): V.

Costello, L.R., and A.M. Berry. 1991. The California tree failure report program: An overview. J. Arboric. 17:250.

Edberg, R.J., A.M. Berry, and L.R. Costello. 1994. Patterns of structural failure in urban trees: Monterey pine. J. Arboric. 20:297.

Geng, S., and FJ. Hills. 1989. Biometrics in Agricultural Science. Kendall/Hunt Publishing, Dubuque, IA.

Griffin, J.R, and W.B. Critchfield. 1972. The distribution of forest trees in California. USDA Forest Service Research Paper PSW-82.

Jacobs, K.A., J.D. MacDonald, A.M. Berry, and L.R. Costello. 1997a. Rooting responses of three oak species to low oxygen stress, pp 91-100. In N.H. Pillsbury, J. Verner, and W.D. Tietje (Eds.). Proceedings of a Symposium on Oak Woodlands: Ecology, Management and Urban Interface Issues. Gen. Tech. Rep. PSW-GTR160, Albany, CA. PSW Res. Station, USDA Forest Service.

Jacobs, K.A., J.D. MacDonald, A.M. Berry, and L.R. Costello. 1997b. The effect of low oxygen stress on Phytophthora cinnamomi infection and disease of cork oak roots, pp 553-558. In N.H. Pillsbury, J. Verner, and W.D. Tietje (Eds.). Proceedings of a Symposium on Oak Woodlands: Ecology, Management and Urban Interface Issues. Gen. Tech. Rep. PSW-GTR-160, Albany, CA. PSW Res. Station, USDA Forest Service.

MacDonald, J.D., L.R. Costello, and T. Berger. 1993. An evaluation of soil aeration status around healthy and declining oaks in an urban environment in California. J. Arboric. 19(4):209-219.

Acknowledgements. Thanks to E. Greg McPherson, U.S. Forest Service, PSW, Western Center for Urban Forest Research and Education, for comments on the first version of this manuscript, and to Ted Elder of Elder \& Elder Ltd., for generous permission to use the photograph in Figure 1.

\section{${ }^{1}$ Assistant Superintendent of Grounds \\ University of California \\ Santa Cruz, CA 95064}
${ }^{2}$ Associate Professor
Department of Environmental Horticulture
University of California
Davis, CA 95616
amberry@uiuc.edu 
Résumé. Les données du California Tree Failure Report Program (programme de cueillette d'informations sur les chutes d'arbres de la Californie) sur le chêne vert de Californie (Quercus agrifolia) ont été analysées afin de préparer un profil des caractéristiques de bris de structure chez cet arbre. Le type le plus commun de bris de structure pour les chênes verts de Californie rapporté dans cette étude est une faiblesse basse dans le tronc ou les racines des arbres poussant naturellement dans les quartiers résidentiels. La carie, les modifications de sites et des vents de faible vélocité sont significativement associés plus souvent avec les chênes verts de la Californie qu'avec tout autre espèce feuillue, conifère ou l'eucalyptus. Quatrevingt-trois pourcent des chutes ont été associées à la carie, tout comme chez les autres espèces de chêne. Le défaut structural majeur noté chez le chêne vert de Californie était que les parties tombées étaient mortes, à la fois au niveau des racines et du tronc. Des chutes étaient aussi plus fréquentes chez le chêne vert de Californie que chez les autres espèces de chêne ou les autres groupes d'arbres en présence de conditions de sols saturés associés à un bris de racines. Une attention particulière doit être apportée en contrôlant les excès d'humidité dans le sol, en évitant ou en corrigeant les effets néfastes des changements de nivellement et de la compaction et effectuant un suivi de l'évolution du processus de carie pour maintenir les chênes verts de Californie en santé.

Zusammenfassung. Die Daten vom Kalifornischen Programm zur Erfassung von Baumversagen von Küsteneichen (Quercus agrifolia) wurden analysiert, um ein Profil der strukturellen Versagenskriterien für diese Baumart vorzubereiten. Die häufigste strukturelle Versagensursache bei Küsteneichen in dieser Studie ist ein Versagen von Wurzeln und StammfulSbereichen bei Bäumen, die in bebauten Gegenden stehen. Fäulnis, Standortveränderungen und geringe Windgeschwindigkeiten sind deutlich häufiger mit Küsteneichen assoziiert als mit anderen Harthölzern, Koniferen oder Eucalyptus. $80 \%$ der Ausfälle wurden, ähnlich wie bei anderen Eichenarten mit Fäulnis assoziiert. Der hauptsächliche strukturelle Defekt bei Küsteneichen war, daßs die umgestürzten Bäume bereits an der Wurzel und im Stammbereich abgestorben waren. Gesättigte Bodenwasserbedingungen in Verbindung mit Wurzelfäule waren bei Küsteneichen häufiger als bei anderen Eichenarten und Baumgrupen zu finden. Aufmerksamkeit bei der Kontrolle des Wassersättigungsgrades der Stanorte, Kontrolle der Bodenverdichtung und des Bodengefüges, sowie die Überwachung von Fäulnis sind notwendig, um die Gesundheit von Küsteneichen zu erhalten.

Resumen. Fueron analizados los datos del Reporte del Programa de Fallas de Arboles de California para robles vivos costeros (Quercus agrifolia) con el fin de preparar un perfil de las características de las fallas estructurales de este árbol. El tipo más común de falla estructural para los robles costeros reportados en este estudio es una falla de la raiz o en la parte baja del tronco de árboles que crecen naturalmente en áreas residenciales. La descomposición, los cambios de sitio, y las velocidades bajas del viento están significativamente asociadas más frecuentemente con el roble costero que con otras latifoliadas, coníferas o Eucalyptus. Ochenta y tres por ciento de las fallas estuvieron asociadas con la descomposición, similar a otras especies de roble. El principal defecto estructural anotado para el roble costero fue que las porciones afectadas estaban muertas, tanto en las raíces como en el tronco. Las condiciones saturadas del suelo asociadas con la falla de la raiz fueron también más frecuentes para el roble costero que para otras especies de roble y otros grupos de árboles. Es esencial la atención cuidadosa para controlar los excesos de humedad del suelo, evitando o corrigiendo los disturbios en compactación y nivel del suelo, y el registro de la descomposición, para mantener la salud de los robles vivos costeros de California. 